\title{
Poisoning in Children and adolescents assisted during the COVID-19 pandemic at the Toxicological Information and Assistance Center in Federal District, Brazil
} (CIATOX -DF): Descriptive, Cross-sectional, and Analytical study with 1.037

\section{patients}

\author{
Intoxicações em crianças e adolescentes atendidas no Centro de Informações e Assistência \\ Toxicológica-CIATOX-DF durante a pandemia de COVID-19: estudo descritivo, transversal e
} analítico com 1.037 pacientes

Intoxicaciones en niños y adolescentes atendidos en el Centro de Información y Asistencia Toxicológica-CIATOX-DF durante la pandemia COVID-19: estudio descriptive, transversal y analítico con 1.037 pacientes

\begin{abstract}
Exogenous poisonings are one of the principal accidents involving children and adolescents. The social isolation promoted by the COVID-19 pandemic raises concerns about the possibility of an increase in poisoning among children since most cases of poisoning occur in home environments. Therefore, the present study evaluated exogenous poisonings in children under ten years of age and adolescents aged 11 to 20 years old through data recorded at the Toxicological Information and Assistance Center in the Federal District (CIATOX-DF) from January to September 2020. The results showed a change in the number of notifications, with 1.037 poisonings registered in patients under 20 years of age. Registrations of poisoning by venomous animals, medications, and household cleaning products in children tend to be higher in months of vacation. This study demonstrated poisoning notifications by non-venomous animals in March and April and household cleaning products as the second leading cause of exogenous poisoning, demonstrating a clear temporal association among social isolation, increased use of household cleaning products, and exposure to these products. The multivariate analysis methodology managed to show the significant characteristics of the studied sample, contributing to creating local actions that aim to reduce the number of preventable cases of poisonings.
\end{abstract}

Keywords: Intoxication; Children; COVID-19; Federal District. 


\section{Resumo}

As intoxicações exógenas são um dos principais acidentes envolvendo crianças. Considerando que a maioria dos casos de intoxicações ocorrem em ambiente domiciliar, o isolamento social resultante da pandemia de Covid-19 levanta preocupações acerca da possibilidade do aumento das intoxicações acidentais entre crianças. Portanto, o presente estudo avaliou os dados de intoxicações exógenas registrados no Centro de Informações e Assistência Toxicológica do Distrito Federal (CIATOX-DF) em crianças menores de 10 anos e adolescentes de 11 a 20 anos, entre janeiro e setembro de 2020. Observou-se que houve uma mudança no quantitativo de casos, sendo registrados 1037 intoxicações em pacientes menores de 20 anos. Os meses de férias são os com maiores números de casos de intoxicações por animais peçonhentos, medicamentos e produtos de uso domésticos em crianças. Neste trabalho foi observado casos de animais não peçonhentos ocorridos nos meses de março e abril e os domissanitários foram a segunda maior causa de intoxicação exógena, demonstrando uma associação temporal clara entre o isolamento social, o aumento do uso desses produtos e as exposições. A metodologia de análise multivariada conseguiu apresentar as características significantes da amostra estudada, colaborando para gerar ações locais no intuito de diminuir o número de casos das intoxicações preveníveis na região.

Palavras-chave: Intoxicação; Crianças; COVID-19; Distrito Federal.

\section{Resumen}

La intoxicación exógena es uno de los principales accidentes que afectan a los niños. Teniendo en cuenta que la mayoría de los casos de intoxicación ocurren en el entorno del hogar, el aislamiento social resultante de la pandemia de Covid-19 genera preocupaciones sobre la posibilidad de un aumento de las intoxicaciones accidentales entre los niños. Por lo tanto, el presente estudio evaluó datos sobre intoxicaciones exógenas registradas en Centro de Información y Asistencia Toxicológica del Distrito Federal (CIATOX-DF) en niños menores de 10 años y adolescentes de 11 a 20 años, entre enero y septiembre de 2020. Se observó que hubo un cambio en el número de casos, siendo 1037 Se registraron intoxicaciones en pacientes menores de 20 años. Los meses de vacaciones son los que presentan mayor número de casos de intoxicaciones por animales venenosos, medicamentos y productos domésticos en los niños. En este estudio, se observaron casos de animales no venenosos ocurridos en marzo y abril, y la limpieza del hogar fue la segunda causa principal de intoxicación exógena, demostrando una clara asociación temporal entre aislamiento social, mayor uso de estos productos y exposiciones. La metodología de análisis multivariado logró presentar las características significativas de la muestra estudiada, colaborando para generar acciones locales con el fin de reducir el número de casos de intoxicaciones prevenibles en la región.

Palabras clave: Intoxicación; Niños; COVID-19; Distrito Federal.

\section{Introduction}

Poisonings are defined as clinical signs of the nocive effects caused by a chemical substance on a living organism (Oliveira \& Suchara, 2014). These substances are found in the environment (plants, venomous or poisonous animals) or as isolated products (pesticides, medications, industrial products, and household cleaning products) (Fukuda et al., 2015). Accidents with children stand out in the context of poisonings due to their high occurrence and morbidity, which can lead to psychological and financial consequences for the child, their family, and society (Farnaghi et al., 2016). In most pediatric poisonings, the substances are minimally toxic but eventually can cause severe symptoms that require medical intervention to prevent injury or death.

Exogenous poisonings are one of the principal accidents involving children and represent about $7 \%$ of accidents in children under five years of age (Lourenço et al., 2008). In pediatrics, they are listed as one of the most common causes in emergency care (Oliveira \& Suchara, 2014) (Farnaghi et al., 2016) and are the second most common cause of child death in these scenarios, second only to car accidents (Farnaghi et al., 2016). Therefore, accidental poisoning is a worldwide public health problem, corresponding to approximately 45 thousand annual deaths with an incidence of 1.8 per 100 thousand inhabitants (Vilaca et al., 2020).

The World Health Organization (WHO) estimates that $1.5 \%$ to $3 \%$ of the population is poisoned every year (Secretaria de Vigilância em Saúde \& Ministério da Saúde, 2018). In 2018 the United States reported more than 2 million cases of poisoning, most of which were unintentional (76.7\%) and expressively occurring with children under 12 years of age $(50.44 \%)^{8}$. In the same year, there were 31.493 cases of acute poisoning in Japan, of which $94.9 \%$ were unintentional, and 
77.9\% occurred with children under 12 years of age (Japan Poison Information Center, 2020). The highest mortality rates associated with unintentional poisonings were registered in Africa and the lowest in the Americas (World Health Organization, 2016).

In Brazil, the National System of Toxic and Pharmacological Information (Sistema Nacional de Informações TóxicoFarmacológicas - SINITOX) registered 76.115 exogenous poisoning cases in 2017 , of which $21.81 \%$ correspond to children under ten years of age, a considerable proportion of the population affected (Sistema Nacional de Informações TóxicoFarmacológicas [SINITOX], 2020). However, studies estimate that about $25 \%$ of poisoning cases in children under six years of age are not notified to the Toxicological Information Centers (Amorim et al., 2017), suggesting an incidence of cases even higher than that presented by SINITOX.

Considering the prevalence of poisoning in the home environment (90\%) (Vilaca et al., 2020), the social isolation as a consequence of the current situation of the COVID-19 pandemic raises concerns about the possibility of an increase in accidental poisoning among children during this period, since they spend most of their time at home. Therefore, the present study aims to evaluate data on exogenous poisoning in children under ten years of age and adolescents aged 11 to 20 years old from February to September 2020, during the COVID-19 pandemic period, and demonstrating its relevance for possible prevention intervention. During the COVID-19 pandemic, schools were closed in the Federal District by the governor's order.

\section{Methodology}

\section{Study design}

A descriptive, cross-sectional and analytical study was developed.

\section{Sample size}

All cases of patients under 20 years of age were evaluated.

\section{Data collect}

Data were taken from Toxicology Information and Assistance Center Program (CIAT DF) version 01, exported and stored in Excel spreadsheets and analyzed using the statistical program Système Portable d'Analyse - SPAD, version 7.4 (Lebart et al., 1994), professional version capable of working with a large number of individuals and variables, from Coheris' producer, a version created in 2010.

The variables studied were: age, sex, toxic agent, the active ingredient, class, region (satellite towns or municipality), call time, poisoning type (acute-single, acute-chronic, acute-on-chronic, chronic, and ignored), category of professional who attended the case, the poisoning circumstance (accidental, environmental, occupational, food, therapeutic use, inappropriate medical prescription, administration error, folk medicine, abstinence, misuse, other non-intentional, self-medication, abuse, suicide attempt, abortion attempt, violence/homicide, and other intentional), route of administration, occurrence area (rural or urban), case evolution, healthcare unit, and final classification (exposure, confirmed poisoning, adverse reaction, differential diagnosis, syndrome abstinence, and ignored).

\section{Statistical analysis}

The data found were quantified and presented in graphs and tables in descriptive frequency analysis and further submitted to Multivariate Data Analysis by Multiple Correspondence Analysis (MCA) and Hierarchical Cluster Analysis (HCA) (Everitt \& Dunn, 2001). 


\section{Multiple Correspondence Analysis (MCA)}

The MCA general conception, among other features, is the inclusion of categorical variables, appropriate for nominal data because it can transform qualitative data into data frequencies, i.e., into quantitative data (Carvalho \& Strunchiner, 1992). It starts from a data matrix and converges to a graph that displays the rows and columns of the matrix as points of a vector space of smaller dimension than the original, to establish relationships between rows, columns, and between rows and columns, that can be interpreted (Greenacre \& Hastie, 1987), it also calculates the eigenvalues and determines the amount of information present on each axis of the graph (Abdi \& Valentin, 2007). This quantitative information represented by information percentages must be reevaluated to discount the overestimation of the coding present in each variable (Greenacre, 2007).

\section{Hierarchical Cluster Analysis (HCA)}

Hierarchical Cluster Analysis (HCA) was used to study the similarities of the samples based on the distribution of variables and represented by the dendrogram. The nearest-neighbor technique by Benzécri's Algorithm (Abdi \& Benzécri, 1979) was applied to verify this similarity, and the hierarchical clusters were formed according to Ward's Minimum-Variance Method (Ward, 1963). P < 0.05 was considered statistically significant (Beebe et al., 1998; Correia \& Ferreira, 2007; Gower, 1966; Hair JR, Black, Babin, Anderson, 2007; Sharaf et al., 1986).

\section{Ethical Aspects}

This project complied with the requirements of the National Health Council Resolution (Conselho Nacional de Saúde - CNS n ${ }^{\circ}$ 466/12) and its supplements. The identification risks of the research subjects were restrained with the cataloging of only their initials by the responsible researcher. The project was submitted to the Oswaldo Cruz Foundation Research Ethics Committee (CEP/Fiocruz) and was approved under number CAAE 35690920.3.0000.8027 on December 11, 2020.

\section{Results and Discussion}

The registers of patients who presented valid data and were assisted at the CIATOX-DF from January to September 2020 showed that 1,037 were under 20 years of age. According to Table 1 and Figure 1, the higher frequencies for different categories were: age range from 2 to 10 years old $(n=439)$, female gender $(n=489)$, February month $(n=140)$, afternoon period $(n=347)$, and poisoning through medication $(n=491)$. Figure 1 shows a higher frequency in children and adolescents when compared to all patients assisted at the CIATOX-DF. 
Table 1: Frequencies of age, sex, month, and toxic agent of patients under 20 years of age assisted at the CIATOX-DF from January to September 2020.

\begin{tabular}{|c|c|c|c|}
\hline $\begin{array}{l}\text { Age range } \\
\text { (years) }\end{array}$ & Frequency & Sex & Frequency \\
\hline$<1$ & $206(9.86 \%)$ & Female & $489(47.15 \%)$ \\
\hline $1-2$ & $161(15.53 \%)$ & Male & $459(44.26 \%)$ \\
\hline $2-10$ & $439(42.33 \%)$ & Ignored & $1(0.09 \%)$ \\
\hline $11-20$ & $231(22.28 \%)$ & Missing data & $88(8.48 \%)$ \\
\hline Total & $1037(100 \%)$ & Total & $1037(100 \%)$ \\
\hline Month & Frequency & Period & Frequency \\
\hline January & $121(11.66 \%)$ & Morning & $127(12.24 \%)$ \\
\hline February & $140(13.50 \%)$ & Afternoon & $347(33.46 \%)$ \\
\hline March & $132(12.72 \%)$ & Evening & $338(32.59 \%)$ \\
\hline April & $118(11.37 \%)$ & Total & $1037(100 \%)$ \\
\hline May & $89(8.58 \%)$ & & \\
\hline June & $90(8.67 \%)$ & & \\
\hline July & $123(11.86 \%)$ & & \\
\hline August & $106(10.22 \%)$ & & \\
\hline September & $118(11.37 \%)$ & & \\
\hline Total & $1037(100 \%)$ & & \\
\hline Toxic Agent & Frequency & Toxic Agent & Frequency \\
\hline Medications & $491(47.34 \%)$ & Plants & $24(2.31 \%)$ \\
\hline $\begin{array}{l}\text { Household cleaning products } \\
\text { (domissanitary) }\end{array}$ & $142(13.69 \%)$ & Venomous animals/spiders & $13(1.25 \%)$ \\
\hline Food & $3(0.28 \%)$ & Venomous animals/snakes & $18(1.73 \%)$ \\
\hline Industrial chemicals & $71(6.84 \%)$ & Venomous animals/caterpillar & $1(0.09 \%)$ \\
\hline Pesticides/household use & $34(3.2 \%)$ & $\begin{array}{l}\text { Other animals } \\
\text { Venomous/poisonous }\end{array}$ & $14(1.5 \%)$ \\
\hline Pesticides/agricultural use & $7(0.67 \%)$ & Drugs of abuse & $12(1.15 \%)$ \\
\hline Veterinary products & $4(0.38 \%)$ & Metals & $1(0.09 \%)$ \\
\hline Venomous animals/scorpions & $70(6.75 \%)$ & Unknown & $6(0.57 \%)$ \\
\hline Raticide & $36(3.47 \%)$ & Others & $10(0.96 \%)$ \\
\hline Cosmetics & $27(2.60 \%)$ & Missing data & $32(3.08 \%)$ \\
\hline Non-venomous animals & $21(2.02 \%)$ & Total & $1037(100 \%)$ \\
\hline
\end{tabular}


Figure 1: Percentage of poisoning/exposure cases classified by patient's age, considering all patients assisted at the CIATOX from January to September 2020.

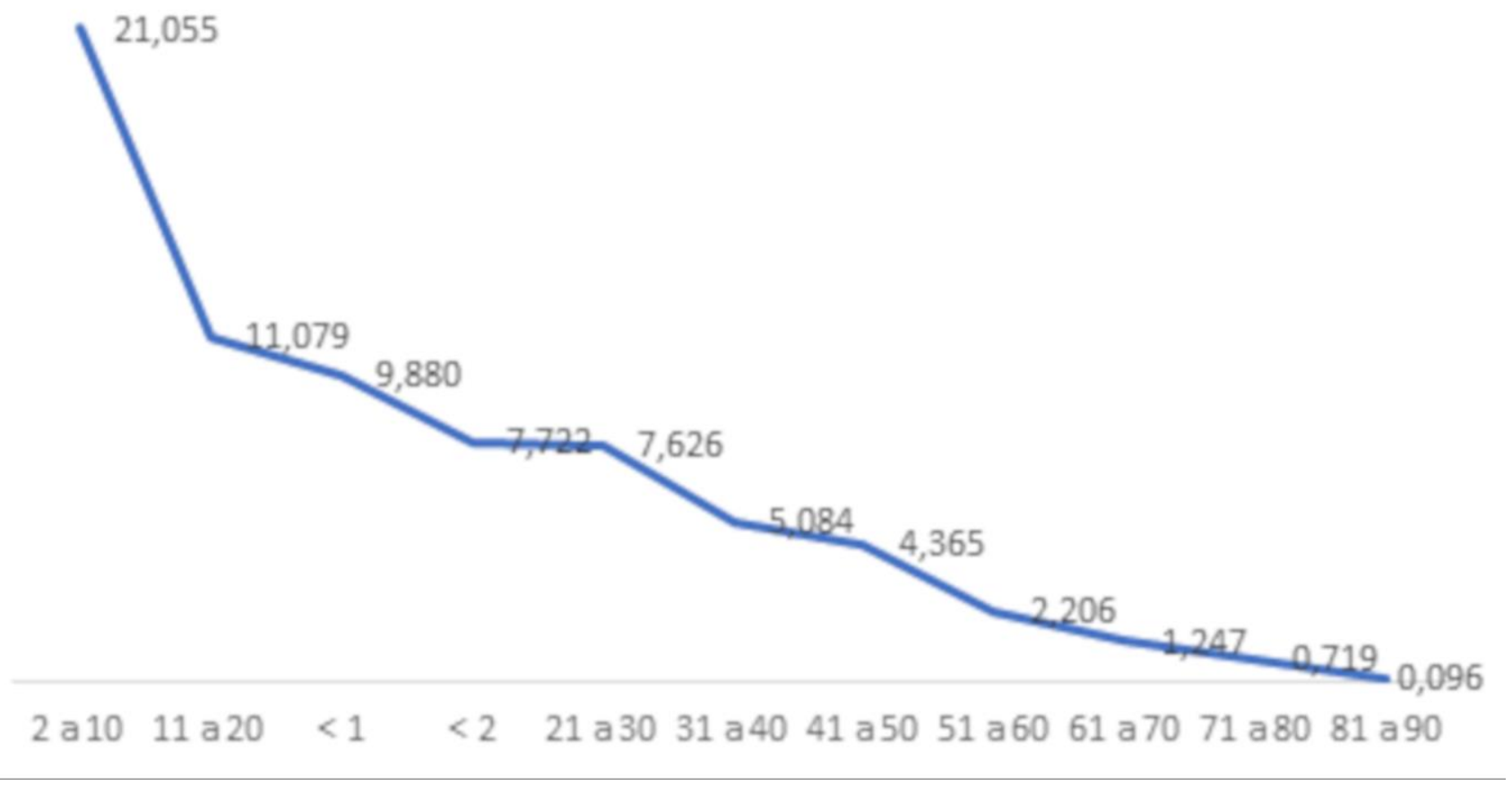

Source: Toxicology Information and Assistance Center Program (CIAT DF) version 01

The Multiple Correspondence Analysis (MCA) showed 51.2\% information in the first three axes. According to the dendrogram generated in the Hierarchical Cluster Analysis (HCA), the patients were grouped into 3 or 24 clusters. The first factorial axis separated the confirmed poisoning cases from the reported cases. The second factorial axis separated patients under ten years old from those above ten years old and the poisoning cases by venomous animals/scorpion from those promoted by other agents, as shown in Figure 2.

Figure 2: MCA graph showing the grouping of patients into three clusters.

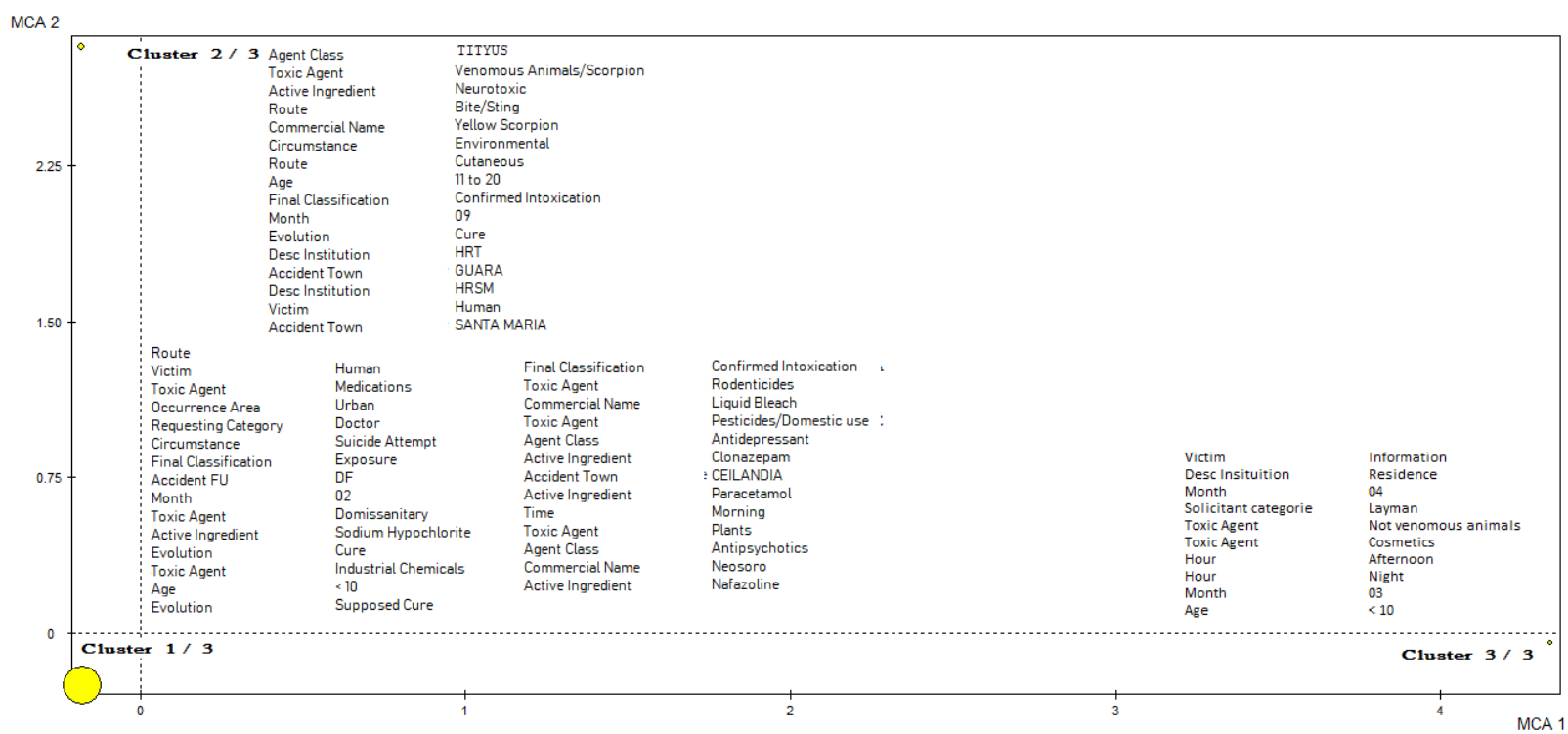

Source: Toxicology Information and Assistance Center Program (CIAT DF) version 01. 
The distribution of the patients into 24 clusters generated the situations shown in figures 3 to 8 . These 24 clusters scattered in mathematical space were presented in figure 3 and their unfoldings in figures 4 to 8 . There was an aggregation of clusters in the lower left quadrant that were analyzed separately and clusters that were considered outliers related to that quadrant.

Figure 3: MCA graph showing the grouping of patients into twenty-four clusters.

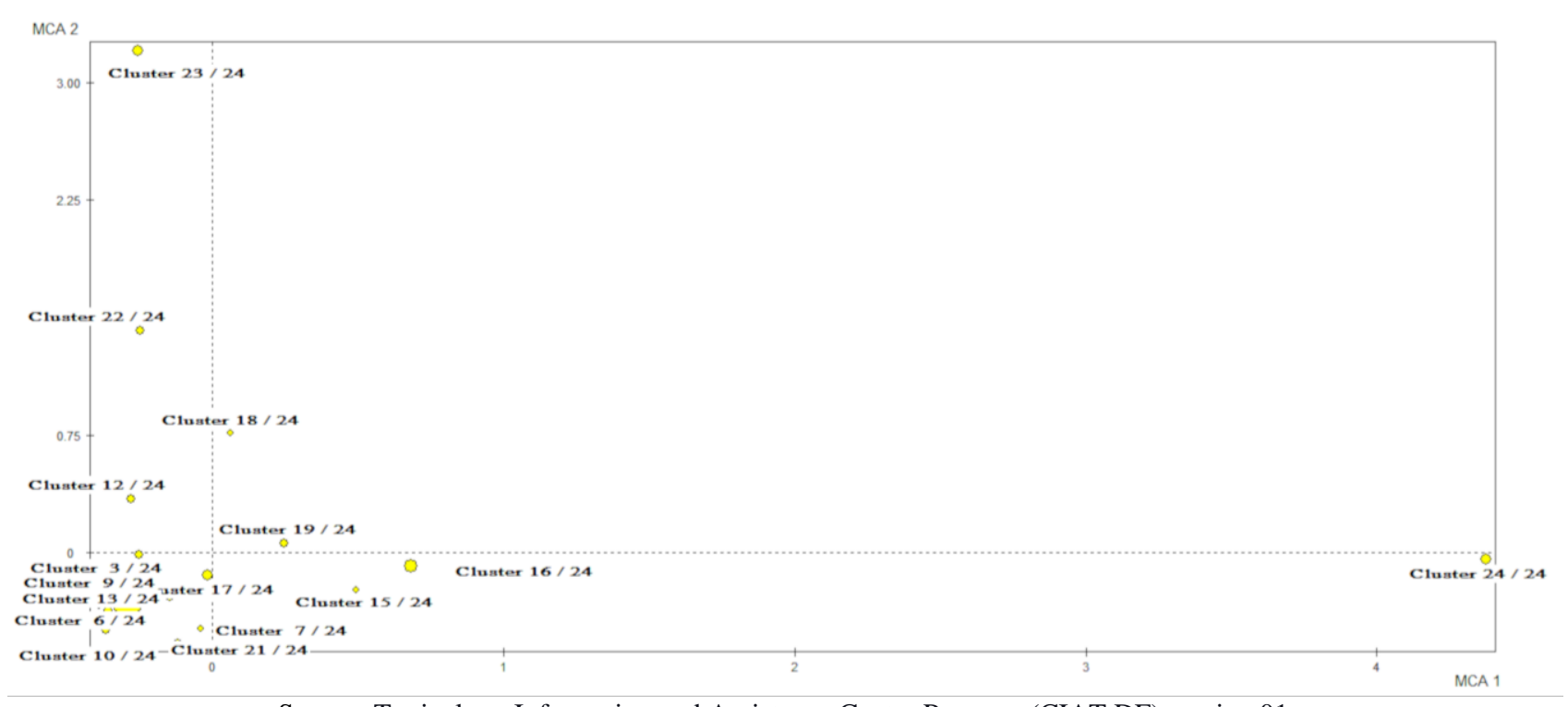

Source: Toxicology Information and Assistance Center Program (CIAT DF) version 01.

The two clusters in the upper right quadrant graph (Figure 4) correspond to the cases of children aged 2 to 10 years old exposed to non-poisonous animals (cluster 18) and children under two years old poisoned by cosmetics in Taguatinga town (cluster 19). This quadrant showed a trend toward cases of younger children.

Figure 4: MCA graph focusing on the upper right quadrant.

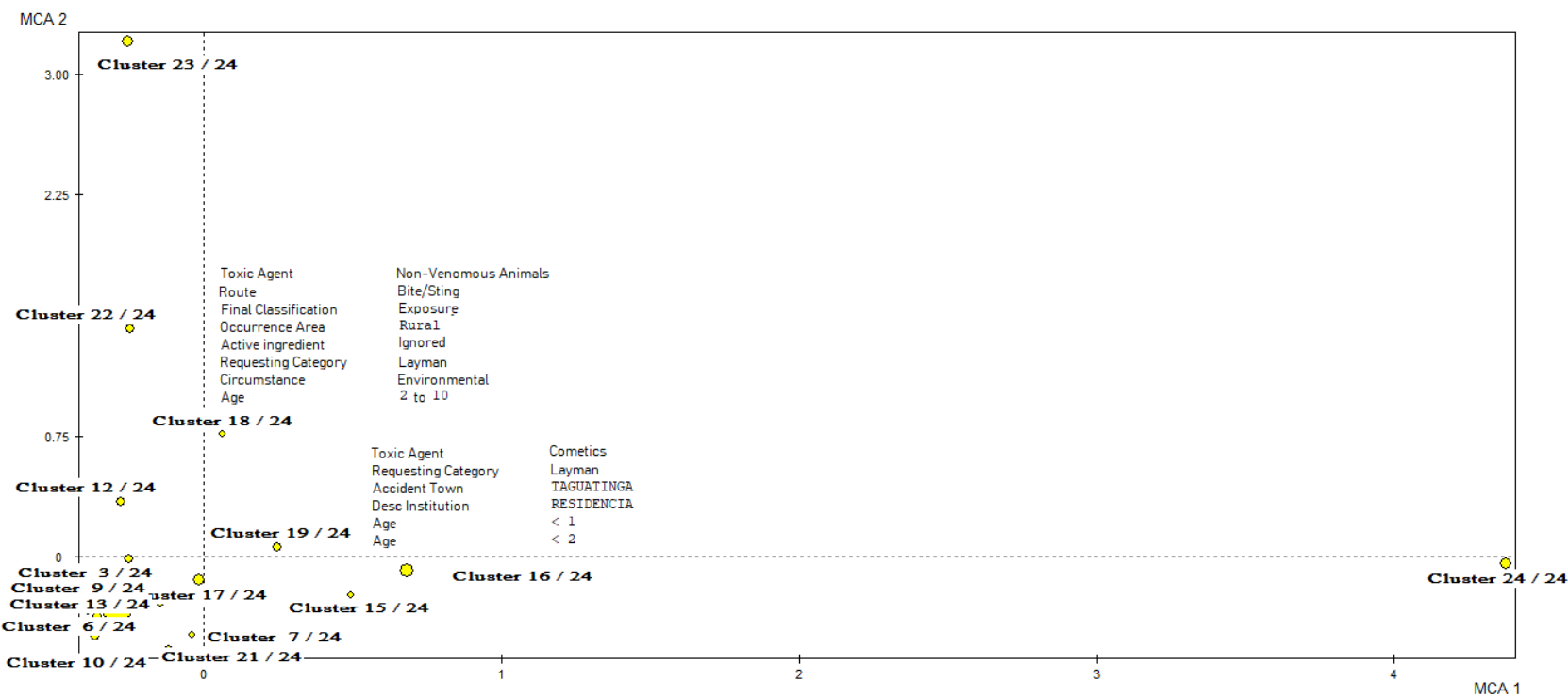

Source: Toxicology Information and Assistance Center Program (CIAT DF) version 01. 
The clusters showed in the upper left quadrant (Figure 5) were characterized by cases of venomous animals/scorpions occurring in Sobradinho and Santa Maria in patients aged 11 to 20 years old (cluster 23); occurring in September (cluster 22); and cases in February and August in São Sebastião in the morning, also in adolescents aged 11 to 20 years old (cluster 12). This quadrant demonstrated a tendency to cases involving scorpions and older individuals in more distant satellite towns.

Figure 5: MCA graph focusing on the upper left quadrant.

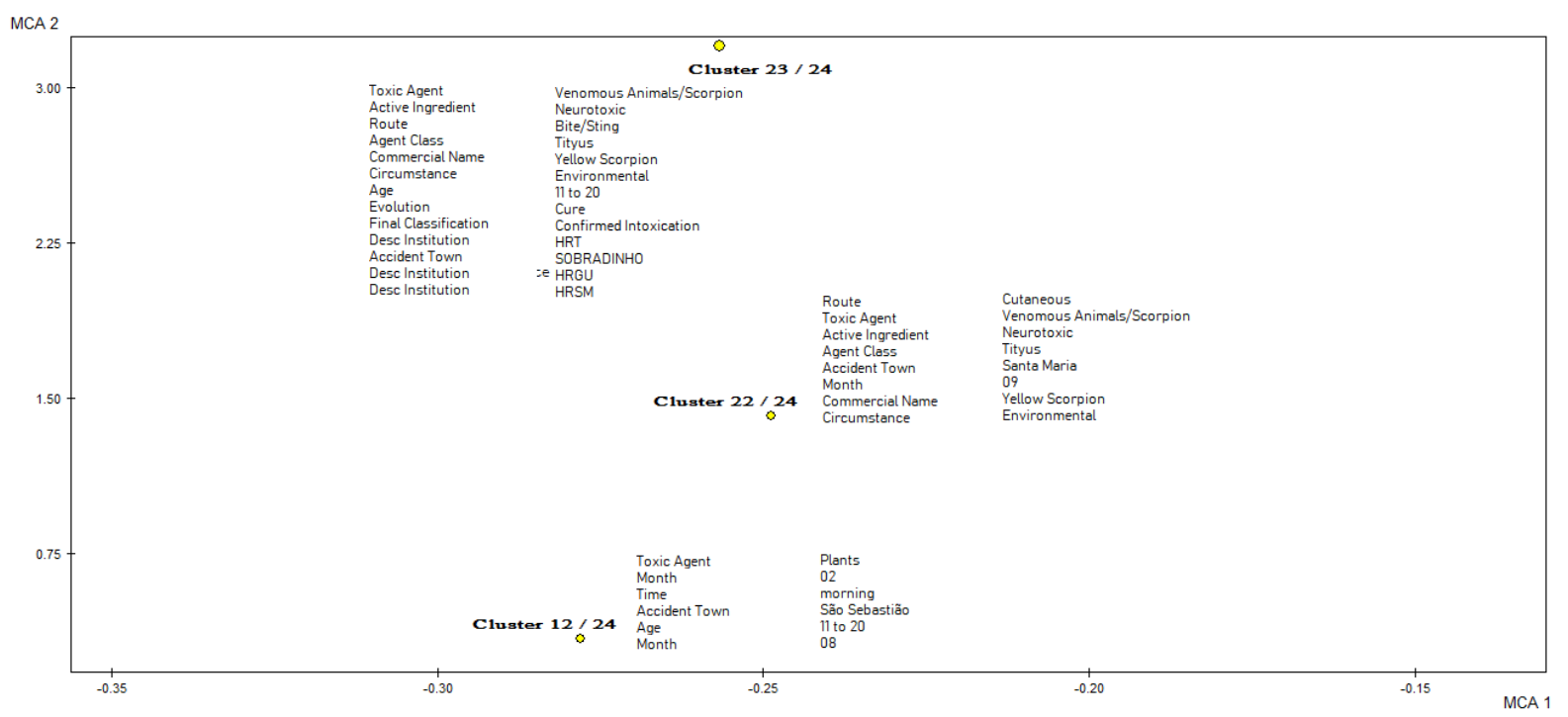

Source: Toxicology Information and Assistance Center Program (CIAT DF) version 01.

Figure 6 showed cases of poisoning by industrial chemicals and antidepressant drugs which occurred accidentally in June and July (cluster 16); information about non-poisonous animals requested by laymen in March and April in the afternoon (cluster 24 away from the others - outlier); cases of general poisoning in male children aged 2 to 10 years old, occurring at night in Santa Maria (cluster 15). This quadrant presents less common cases with a trend toward children aged 2 to 10 years old.

Figure 6: MCA graph focusing on the lower right quadrant.

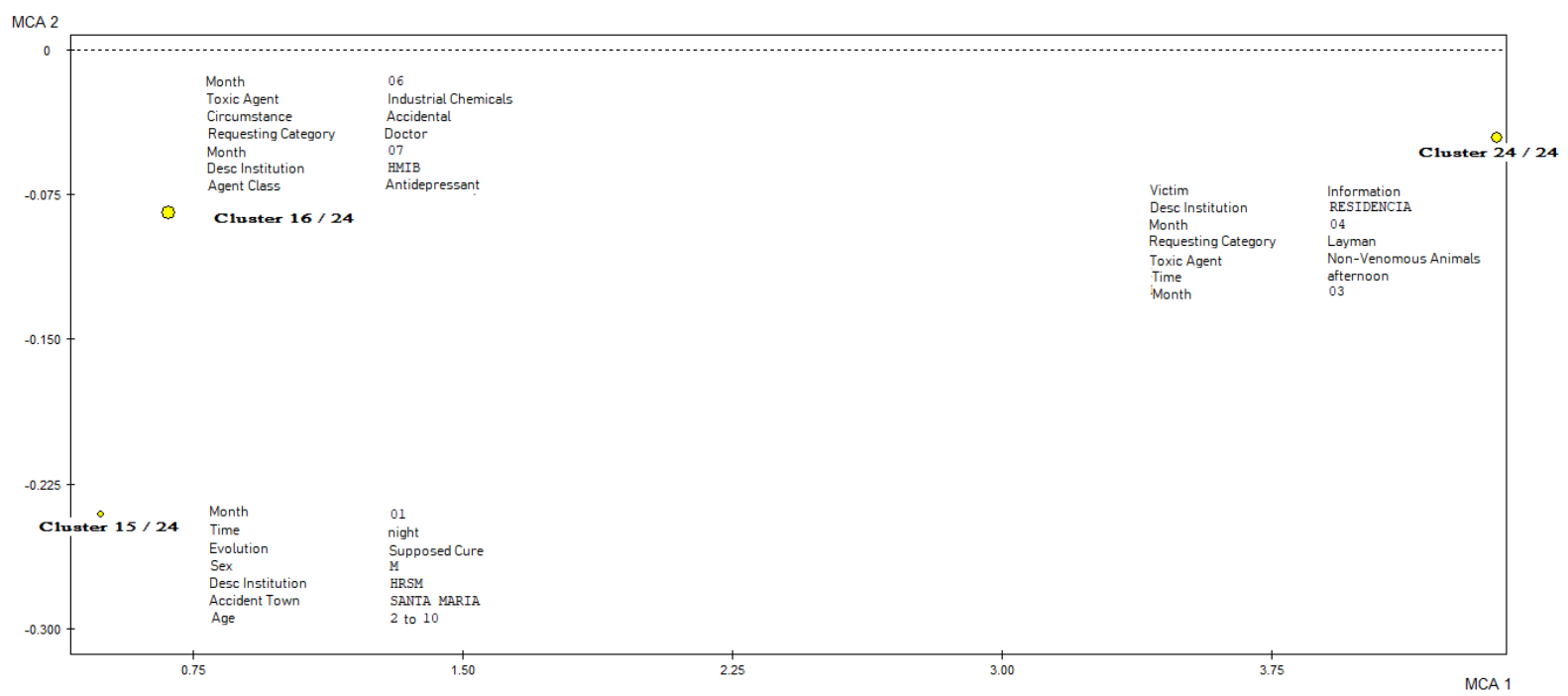


Source: Toxicology Information and Assistance Center Program (CIAT DF) version 01.

The cases showed in the lower left quadrant were depicted in Figures 7 and 8. In this quadrant, clusters of the right side (Figure 7) showed cases: of poisoning assisted in Santa Maria (cluster 3); poisoning by rodenticide in children aged 2 to 10 years old, assisted in Samambaia, in January and February (cluster 2); exposure to household pesticides that occurred with children aged 2 to 10 years old (cluster 17) and domissanitary assisted in Taguatinga in July (cluster 7). This quadrant shows a trend of cases in children aged 2 to 10 years by pesticides and rodenticides.

Figure 7: MCA graph focusing on the lower left quadrant emphasizing clusters on the right side.

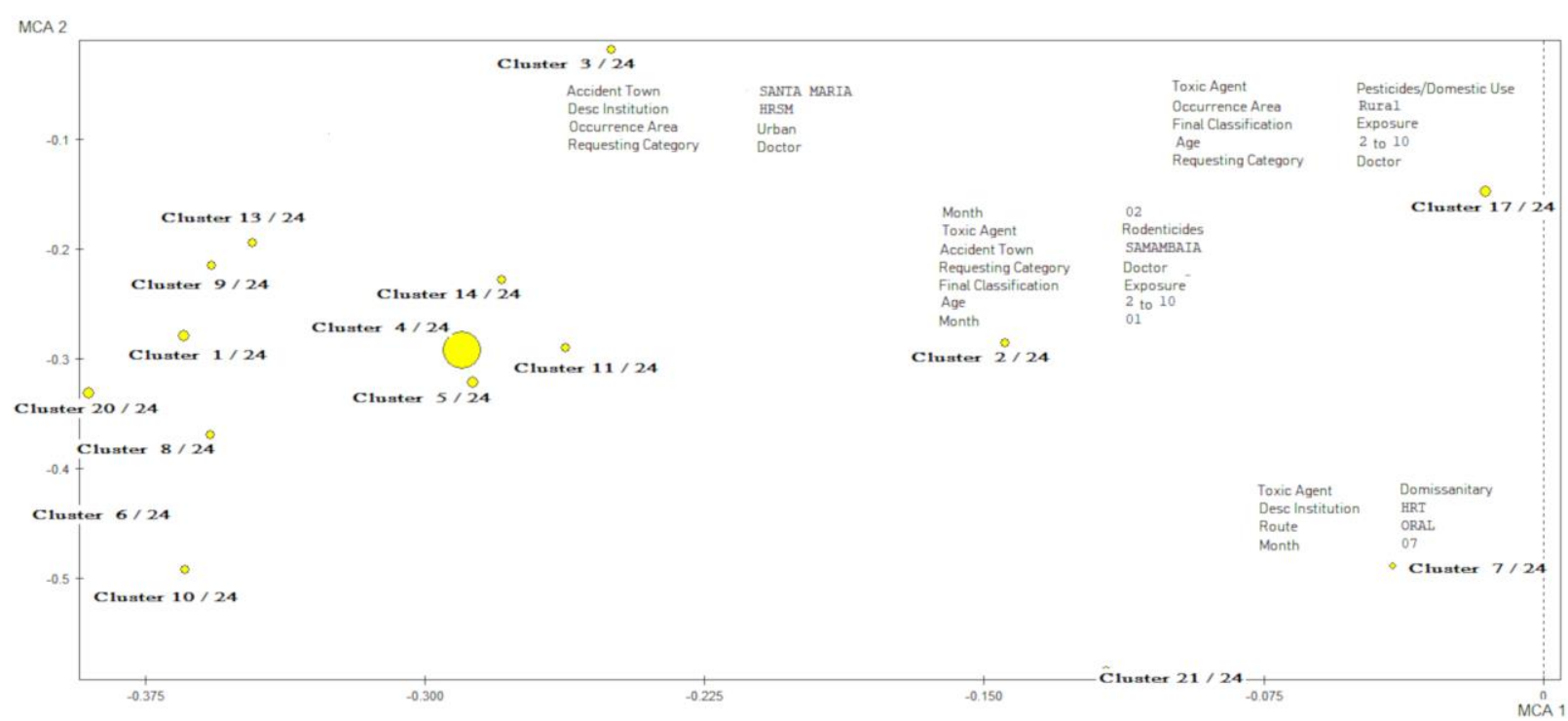

Source: Toxicology Information and Assistance Center Program (CIAT DF) version 01.

The cases on the left side (Figure 8) grouped: medication poisonings in children under 1-year-old (cluster 10); medications in suicide attempts in children under ten years old (cluster 20); industrial chemicals, medications, and household cleaning products in June (cluster 8 and 4); household cleaning products in children under two years old assisted in Guará (cluster 5); and exposure cases to rodenticides in São Sebastião (cluster 11). Cluster 4 presented the highest cases number. This quadrant shows a trend for patients under two years of age exposed to different toxic agents. 
Figure 8: MCA graph focusing on the lower left quadrant emphasizing clusters on the left side.

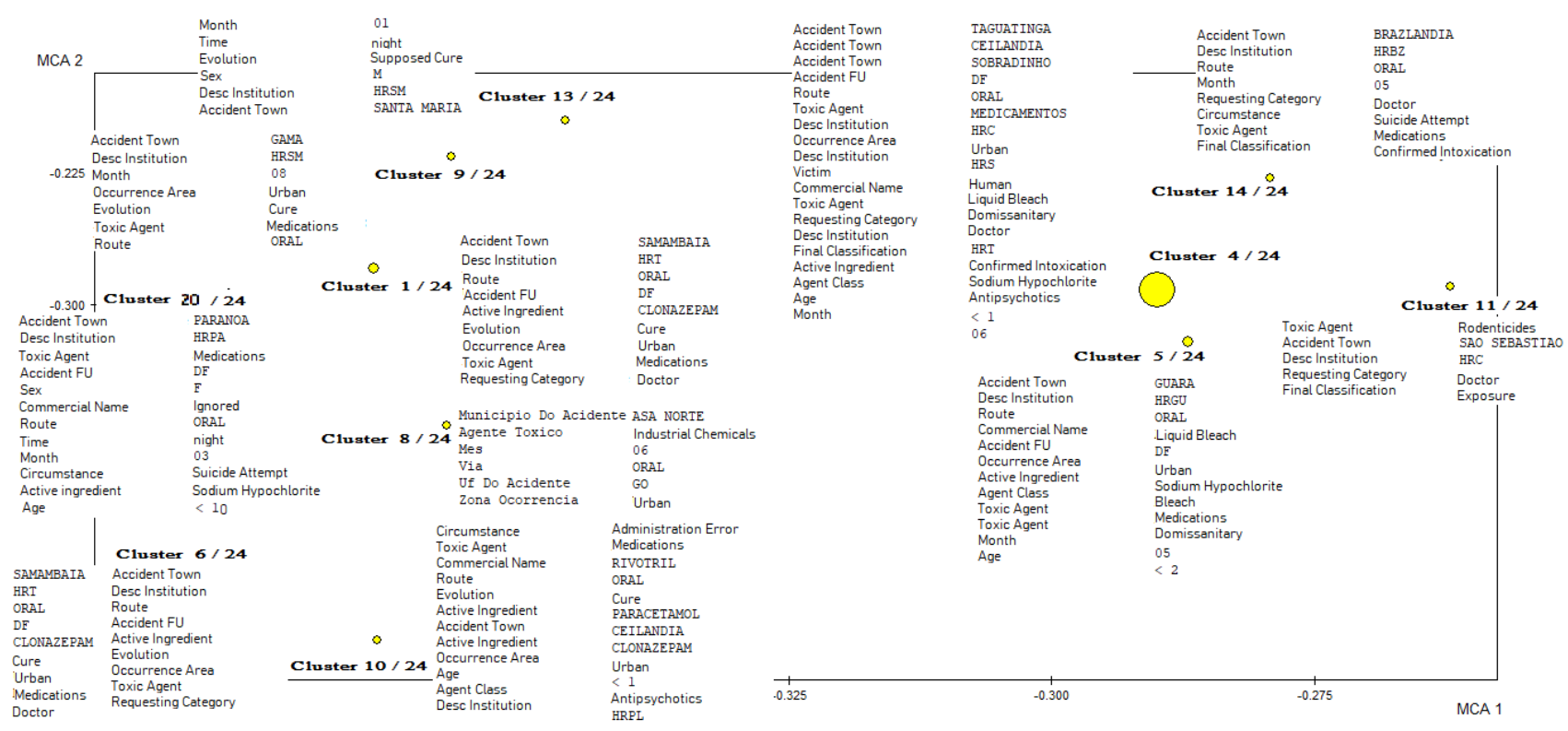

Source: Toxicology Information and Assistance Center Program (CIAT DF) version 01.

It is noteworthy that the groups without age indication were influenced by patients belonging to close groups.

\section{Discussion}

The present study results showed exogenous poisoning rates of $21.05 \%$, in ages 2 to 10 years old, from January to September 2020. This number is consistent with that detected by SINITOX, nationally, in 2017 (21.81\%) for children aged 0 to 10 years old (Sistema Nacional de Informações Tóxico-Farmacológicas [SINITOX], 2020). According to the Department of Informatics of the Unified Health System of Brazil (DATASUS), in 2020, the rates of exogenous poisoning in the Federal District, in children aged 0-9 years old, corresponding to $15.6 \%$ of total poisonings (Departamento de Informática do Sistema Único de Saúde [DATASUS] \& Informações de Saúde (TABNET), 2020). In the right and lower left quadrants (Figure 3, 5, 6, and 7) were demonstrated groups of children under ten years of age, showing a variety and a higher number of cases. The pediatric age range, in general, presents a large proportion of poisoning cases, factors related to the characteristics of the child development phases involving curiosity and the habit of carrying colored substances or objects in the mouth make this age group more vulnerable to exogenous poisoning (Oliveira \& Suchara, 2014). Similarly, other factors such as improper storage location for hazardous chemicals, lack of supervision, facilitated access to medications in-home and out-of-home environments, and little incentive of preventive measures (Fukuda et al., 2015) also contribute to such poisoning accidents.

Regarding the sexes frequency, this study showed a lower frequency of males $(44.62 \%)$ while females were $47.15 \%$ (Table 01). These data vary within poisoning studies and may present significant differences or similar percentages. However, most previous studies have shown a higher males poisoning prevalence (Vilaca et al., 2020) (Geith et al., 2018) (Domingos et al., 2016), as demonstrated in studies conducted in different states.

A study conducted in northern Pará showed a frequency of 51.1\% poisoning cases in boys (Fukuda et al., 2015). In Belo Horizonte (Minas Gerais), the toxicology sector of a public reference hospital demonstrated poisoning prevalence in male individuals up to 2 years old and similar frequencies between genders in the age range from 3-12 years of age (Vilaca et al., 2020). A study conducted in Goiânia (Goiás) showed that most cases of poisoning involved male children (51.2\%) (Siqueira et 
al., 2008). In the Federal District, in 2020, within the population from 0-9 years of age, 54.16\% of poisonings occurred in males (Departamento de Informática do Sistema Único de Saúde [DATASUS] \& Informações de Saúde (TABNET), 2020).

The prevalence of poisonings in male children may be interpreted under the cultural aspect since families tend to educate boys with less vigilance. In consequence, they have less direct adult supervision than girls (Siqueira et al., 2008).

Otherwise, considering the population up to 20 years of age, these proportions change. In 2020 in the Federal District, $57.93 \%$ of poisonings occurred in females aged 0-19 years old (Departamento de Informática do Sistema Único de Saúde [DATASUS] \& Informações de Saúde (TABNET), 2020). A study conducted in Mato Grosso showed a prevalence of poisonings in female children when extending the age range from 0-19 years old, with the most expressive number from 15-19 years old (Oliveira \& Suchara, 2014). These results are similar to those demonstrated in this study. However, the differences between the gender percentages were non-significant statistically, lying within the error percentage.

No gender differences were showed in studies conducted in Northeast Brazil (Amorim et al., 2017) and Mato Grosso (Oliveira \& Suchara, 2014). No significance was observed in the MCA for gender.

This study showed a higher number of cases in February (13.5\%) followed by March (12.79\%), July (11.86\%), January (11.66\%), April/September (11.37\%), August (10.22\%), June (8.67\%) and May (8.58\%) (Table 01). Months with more occurrences and increase in poisoning rates are compatible with the long time children stayed at home due to social isolation, as reported by previous studies that showed higher poisoning rates in the home environment (Vilaca et al., 2020). Similarly, during the months corresponding to vacations, children stay at home longer and seek new activities, becoming more exposed to household cleaning products and medications in-home, and poisonous animals outdoors (Fukuda et al., 2015).

The MCA analysis showed significant correlations between months and poisoning events, as follow: March and April with cases involving non-poisonous animals in the afternoon; January and February with cases involving rodenticide in children aged 2 to 10 years old, assisted in Samambaia; July with domestic pesticide exposures in children aged 2 to 10 years old; and June with industrial chemicals, medications, and household cleaning products exposure.

There was a change in the number of poisoning cases from January to September 2020. According to Fukuda and collaborators (2015) (Fukuda et al., 2015), the vacation months are the highest in the number of poisoning cases by poisonous animals, medications, and household products in children. The present study showed non-poisonous animals cases in March and April (cluster 24). In pre-adolescents and adolescents, there were poisoning cases by scorpions in September (cluster 22) and poisoning cases by plants in February (cluster 12).

Regarding toxic agents, the results showed that from January to September 2020, medications were the main poisoning causative agents in individuals under 20 years of age, corresponding to $47.34 \%$ of the cases (Table 01). It is consistent with the national pattern, in which poisoning by medications was approximately 33\% in 2017 (Sistema Nacional de Informações Tóxico-Farmacológicas [SINITOX], 2020). Also, it is in good agreement with previous studies that showed medications as the principal poisoning causative agent in children (Lourenço et al., 2008; Vilaca et al., 2020) (Amorim et al., 2017) (Geith et al., 2018) (Domingos et al., 2016) (Carla Luiza Job Ramos et al., 2010).

This prevalence may be attributed to several factors, mainly related to parents or caregivers since children do not have easy access to these substances. Also, it is noteworthy to mention the mistakes made in the intake of the medications, such as use without prescription, overdosage, and incorrect timing of administration, which may cause poisoning by the cumulative effect of the substance (Fukuda et al., 2015). Moreover, it is also worth considering the easy availability of medications in homes and the extensive variety in Brazil (Oliveira \& Suchara, 2014). One should also consider the child's curiosity about the contents of jars, closed glasses with colored liquids and tablets, the pleasant taste, the attractive format, and the facility in 
Research, Society and Development, v. 10, n. 15, e25101521960, 2021

(CC BY 4.0) | ISSN 2525-3409 | DOI: http://dx.doi.org/10.33448/rsd-v10i15.21960

violation of the packaging (Siqueira et al., 2008). Furthermore, it is noteworthy that children reproduce the actions of adults and can be poisoned by repeating the watched act (Carla Luiza Job Ramos et al., 2010; Siqueira et al., 2008).

Since medications are presented with a higher proportion of poisoning cases, it is necessary to adopt preventive measures for children's protection, such as protective packaging, cabinets and drawers with keys, and commercialization with non-lethal doses (Amorim et al., 2017).

The ingestion of household cleaning products was the second leading cause of exogenous poisoning, corresponding to $13.69 \%$ of cases in the period studied (Table 01). The MCA showed a strong relationship between domissanitary products and children under two years of age (according to figure 7, cluster 5). This result is in good agreement with findings in Londrina (Paraná), in which poisoning by household cleaning products was the third largest cause of poisonings events with $17 \%$. Accidents caused by venomous animals ranked first (Fukuda et al., 2015). Furthermore, it is in complete agreement with previous findings in northeastern Brazil, with $30.5 \%$ of the poisonings events caused by domissanitary ranked second (Amorim et al., 2017). On the other hand, a survey conducted in Rio de Janeiro, metropolitan region, found poisoning by household cleaning products as the first cause of exogenous poisoning in the pediatric age group, with $39 \%$ of the cases (Werneck \& Hasselmann, 2009), a proportion significantly higher than the present study.

In Brazil, comparing poisoning cases one year before the COVID-19 pandemic and the first months of the pandemic was found that in the period between January and April 2020, there was an increase of $6.01 \%$ in poisoning cases by household pesticides, compared to the same period in 2019 (Agência Nacional de Vigilância Sanitária (ANVISA), 2020). Thus, there seems to be a clear temporal association between the COVID-19 pandemic, the increased use of these products, and exposures (Agência Nacional de Vigilância Sanitária (ANVISA), 2020).

In this study, venomous animals accidents were the third leading cause of exogenous poisoning in childhood, scorpion accidents were the most relevant, with $6.75 \%$ of the cases (Table 01). In Paraná, accidents caused by poisonous animals were just over $21 \%$ of the occurrences, ranked second as a toxic agent (Fukuda et al., 2015). A probable explanation is the children's curiosity and exploratory spirit at older ages, exposing them to risks (Oliveira \& Suchara, 2014). Other factors to be considered are high population density, disorder population growth, and accumulation of garbage favoring the proliferation of cockroaches (scorpion's food) (Amorim et al., 2017).

Appropriate strategies are necessary for the control and prevention of accidents by venomous animals, focusing on scorpions. As well as combating the illegal sale of pesticides, such as rodenticides, for unusual purposes (Amorim et al., 2017).

In this study, $6.84 \%$ of the exogenous poisonings were caused by industrial chemicals (Table 01), being the fourth leading cause. The proximity of the clusters presented in Figure 7, analyzed by the MCA, showed a trend correlation between industrial chemicals and children under two years of age. These data are consistent with those carried out in Londrina (Paraná), in which industrial chemicals were the fifth cause of exogenous poisoning (Fukuda et al., 2015). In another study, the poisoning percentage by this substance was lower, being 5.6\% (Oliveira \& Suchara, 2014). In Goiânia (Goiás), a study revealed that $12 \%$ of childhood poisonings were caused by industrial chemicals, with caustic soda ingestion leading the causal agents (Siqueira et al., 2008).

There was found $3.47 \%$ of the exogenous poisoning cases corresponding to rodenticides (Table 01). The Multiple Correspondence Analysis (MCA) showed a tendency between children exposed to rodenticides in São Sebastião town to be under two years of age (figure 7) and poisoning in children from 2 to 10 years old assisted in Samambaia in January and February (figure 6, cluster 2). These substances were responsible for 6.68\% of exogenous poisonings in Londrina (Paraná), the fifth leading cause (Fukuda et al., 2015). This agent represented 8\% of the poisoning cases in a town in Mato Grosso (Oliveira \& Suchara, 2014) and was the second most frequent group in the childhood exogenous poisonings in Goiânia (Goiás) (Siqueira 
Research, Society and Development, v. 10, n. 15, e25101521960, 2021

(CC BY 4.0) | ISSN 2525-3409 | DOI: http://dx.doi.org/10.33448/rsd-v10i15.21960

et al., 2008). A specific substance was responsible for most of these poisonings, "chumbinho", a rodenticide usually sold illegally. In Rio de Janeiro, about poisonings caused by pesticides, almost $10 \%$ were caused by "chumbinho" 32 . It is noteworthy that this rodenticide is highly lethal and was related to half of the deaths recorded for exogenous poisoning in the pediatric age range (Amorim et al., 2017).

There were found $5 \%$ of the acute exogenous poisoning caused by pesticides, with $3.27 \%$ referring to household pesticides (Table 01). There was a strong correlation between exposure to household pesticides and children aged 2 to 10 years of age (cluster 17). These findings are consistent with those found in Paraná, where the percentage was $8.78 \%$ (Fukuda et al., 2015). In a smaller proportion in Goiânia (Goiás) was found $4 \%$ of poisoning caused by pesticides (Siqueira et al., 2008). In Belo Horizonte (Minas Gerais), pesticides (pesticides and rodenticides) caused $11.1 \%$ of poisonings (Vilaca et al., 2020).

The proportion of exogenous poisonings by cosmetics was $2.6 \%$ in the presented study, whereas the percentage found in Belo Horizonte (Minas Gerais) was 2\% (Vilaca et al., 2020), representing a substantially lower percentage.

Regarding periods of the day when poisonings events occurred, there were found the highest rates in the afternoon (33.46\%) and at night (32.59\%) (Table 1), which is related to the time that children spend in the home environment during these periods (Brito \& Martins, 2015). The Multiple Correspondence Analysis (MCA) showed higher poisoning cases in the night period in children aged 2 to 10 years old (cluster 15). Plant poisoning cases occurred in the morning (cluster 12). A study performed in Pernambuco state in 2006 evaluated exogenous poisoning in children aged 0 to 12 years old and found similar results, with $42.3 \%$ of the occurrences in the afternoon and $38.5 \%$ at night (Lourenço et al., 2008).

Regarding the time of the poisonings, a study performed in the Rio Grande do Sul state in 2003 evaluated cases in children aged 0 to 4 years of age showing a higher frequency between 6:01 pm and $10 \mathrm{pm}(24.8 \%)$ followed by the period from 12:01 am to $3 \mathrm{pm}(20.6 \%$ ) (C L J Ramos et al., 2005). In contrast with these findings, a retrospective study from 2006 to 2001, conducted in a hospital in Paraná state, showed 55.6\% of the poisoning cases occurring in the morning (7:01 am to 1 pm), followed by $42.9 \%$ in the afternoon (1:01 pm to $7 \mathrm{pm})($ Domingos et al., 2016).

Poisoning can lead to irreversible sequelae since children are constantly developing cognitive and psychomotor skills (Fukuda et al., 2015). The methodology of multivariate analysis was able to present the significant characteristics of the sample studied, highlighting regional similarities of patients in the Federal District, collaborating to generate local public service actions to reduce the number of poisoning cases in the region. Thus, prevention of such occurrences is fundamental, and these factors are generally preventable (Lourenço et al., 2008).

\section{Final Considerations}

Based on our findings, we intend to encourage the analysis of public data regarding patterns of patient behavior. By performing this constant monitoring, managers will have the information promptly for decision making. In toxicology, it is crucial to obtain information about the location and period of poisoning occurrences since this influences the redirection of resources and government structures to the regions of greatest need.

This study offers the understanding of several factors such as screening consumption drugs route, venomous animals species cataloging according to the region, and knowledge about new adverse reactions to drugs present in the therapy.

In addition, our data contribute to verifying unpredictable poisonings, which can only be studied in accidental cases, such as in pregnant women or other specific situations.

\section{Acknowledgments}

We thank the Poison Center, the Mobile Emergency Care Service, the Health Regulatory Complex of the Federal 
Research, Society and Development, v. 10, n. 15, e25101521960, 2021

District, the Foundation for Teaching and Research in Health Sciences, and the State Secretariat of Health of the Federal

District for supporting this work.

\section{References}

Abdi, H., \& Benzécri, J. (1979). Pratique de l'analyse des données. In Linguistique et lexicologie. Dunod.

Abdi, H., \& Valentin, D. (2007). Multiple correspondence analysis. In Encyclopedia of measurement and statistics (pp. 651-657). SAGE Publications.

Agência Nacional de Vigilância Sanitária (ANVISA). (2020). Nota técnica $n^{o}$ 11/2020. Alerta sobre o aumento da exposição tóxica por produtos de limpeza no Brasil desde o início da pandemia de Coronavírus - Covid- 19. http://buscajuventude.ibict.br:8080/jspui/bitstream/123456789/419/1/ NTn11.2020_SEI.GHBIO.GGMON.DIRE5.ANVISA_13.05.2020.pdf

Amorim, M. L. P., Mello, M. J. G. D., \& Siqueira, M. T. D. (2017). Poisoning in children and adolescents notified at a toxicology center in the Northeast of Brazil. Rev. Bras. Saude Mater. Infant., 17(4), 765-772.

Beebe, kenneth R., Peli, R. J., \& Seasholtz, M. B. (1998). Chemometrics: a practical guide. Wiley.

Brito, J. G., \& Martins, C. B. (2015). Accidental intoxication of the infant-juvenile population in households: profiles of emergency care. Rev Esc Enferm USP, 49(3), 373-380.

Carvalho, M. S., \& Strunchiner, C. J. (1992). Análise de correspondência: uma aplicação do método à avaliação de serviços de vacinação. Cad Saúde Pública, $8(3), 287-301$.

Correia, P., \& Ferreira, M. (2007). Reconhecimento de padrões por métodos não supervisionados: explorando procedimentos quimiométricos para tratamento de dados analíticos. Química Nova, 30(2), 481.

Departamento de Informática do Sistema Único de Saúde [DATASUS], \& Informações de Saúde (TABNET). (2020). Intoxicação exógena - notificações registradas no SINAN NET - Distrito Federal. http://tabnet.datasus.gov.br/cgi/tabcgi.exe?sinannet/cnv/IntoxDF.def

Domingos, S. M., Borghesan, N. B., Merino, M. F., \& Higarashi, I. H. (2016). Poison-related hospitalizations of children aged 0-14 at a teaching hospital in Southern Brazil, 2006-2011. Epidemiol Serv Saude, 25(2), 343-350.

Everitt, B. S., \& Dunn, G. (2001). Applied Multivariate Data Analysis. Arnold.

Farnaghi, F., Manouchehrifar, M., Shojaee, M., Sabzghabaei, A., \& Derakhshandeh, N. (2016). An epidemiologic study of pediatric poisoning; a six-month cross-sectional study. Emergency, 4(1), 21-24.

Fukuda, R. C., Silva, L. D. G., \& Tacla, M. T. G. M. (2015). Intoxicações exógenas em pediatria. Revista Varia Scientia - Ciências Da Saúde, 1.

Geith, S., Ganzert, M., Schmoll, S., Acquarone, D., Deters, M., Sauer, O., Stürer, A., Tutdibi, E., Wagner, R., \& Eyer, F. (2018). Intoxications in Children and Adolescents in Germany. Klin Padiatr., 230(4), 205-214.

Gower, J. C. (1966). Some distance properties of latent root and vector methods used in multivariate analysis. Biometrika, 53(3-4), 325-338.

Greenacre, M. (2007). Correspondence Analysis in Practice. Chapman and Hall.

Greenacre, M., \& Hastie, T. (1987). The geometric interpretation of correspondence analysis. Journal of the American Statistical Associatino, 82(398), 437447.

Hair JR, J.F., Black, W.C., Babin, B.J, Anderson, R. E. (2007). Análise Multivariada de Dados. Bookman.

Japan Poison Information Center. (2020). Annual Inquiry Summary 2018. https://www.j-poison-ic.jp/english/annual-inquiry-summary/.

Lebart, L., Morineau, A., Lambert, P., \& Pleuvert, P. (1994). Sistema compatible para el análisis de datos. In Manual de referencia. SPAD N: Versión 2.5. Centre International de Statisque et d'Informatique Apliques.

Lourenço, J., Furtado, B. M. A., \& Bonfim, C. (2008). Intoxicações exógenas em crianças atendidas em uma unidade de emergência pediátrica. Acta Paul Enferm, 21(2), 282-286.

Oliveira, F. F., \& Suchara, E. A. (2014). Epidemiological profile of exogeneous poisoning in children and adolescents from a municipality in the state of Mato Grosso. Rev Paul Pediatr, 32(4), 299-305.

Ramos, C L J, Targa, M. B. M., \& Stein, A. T. (2005). Perfil das intoxicações na infância atendidas pelo Centro de Informação Toxicológica do Rio Grande do Sul (CIT/RS), Brasil. Cad. Saúde Pública, 21(4), 1134-1141.

Ramos, Carla Luiza Job, Barros, H. M. T., Stein, A. T., \& Costa, J. S. D. da. (2010). Fatores de risco que contribuem para o envenenamento pediátrico. J. Pediatri. (Rio J), 86(5), 435-440.

Secretaria de Vigilância em Saúde, \& Ministério da Saúde. (2018). Boletim Epidemiológico: Intoxicações exógenas relacionada ao trabalho no Brasil, 20072016. 49, 1-10.

Sharaf, M. A., Illman, D. L., \& Kowalski, B. R. (1986). Chemometrics. Wiley. 
Research, Society and Development, v. 10, n. 15, e25101521960, 2021

(CC BY 4.0) | ISSN 2525-3409 | DOI: http://dx.doi.org/10.33448/rsd-v10i15.21960

Siqueira, K. M., Brandão, J. R., Lima, H. F., Garcia, A. C. A., Gratone, F. M., \& Brasileiro, M. S. E. (2008). Perfil das intoxicações exógenas infantis atendidas em um hospital especializado da rede pública de Goiânia-GO. Rev. Eletr. Enf., 10(3), 662-672.

Sistema Nacional de Informações Tóxico-Farmacológicas [SINITOX]. (2020). Dados de intoxicação. https://sinitox.icict.fiocruz.br/dados-nacionais.

Vilaca, L., Volpe, F. M., \& Ladeira, R. M. (2020). Accidental Poisoning in Children and Adolescents Admitted to a Referral Toxicology Department of a Brazilian Emergency Hospital. Rev Paul Pediatr, 38, e2018096.

Ward, J. H. (1963). Hierarchical grouping to optimize an objective function. Journal of the American Statistical Association, 58(301), $236-244$.

Werneck, G. L., \& Hasselmann, M. H. (2009). Intoxicações exógenas em crianças menores de seis anos atendidas em hospitais da região metropolitana do Rio de Janeiro. Rev. Assoc. Med. Bras., 55(3), 302-307.

World Health Organization. (2016). World Health Statistics 2020: Monitoring Health for the SDGs, sustainable development goals. World Health Organization, 1.121. 